\title{
Does Fertigation With Fish Farming Effluent Alter the Morphophysiology and Biochemistry of Lippia Gracilis (Verbenaceae)?
}

José Maria Damasceno Silva Neto

Universidade do Estado do Rio Grande do Norte

Marciana Bizerra de Morais ( $D$ marciana.bio@gmail.com )

Universidade do Estado do Rio Grande do Norte https://orcid.org/0000-0001-5074-5244

Nildo da Silva Dias

Universidade Federal Rural do Semi-Arido

Lindomar Maria de Souza

Universidade Federal Rural de Pernambuco

Mayron Alves Vasconcelos

Universidade do Estado de Minas Gerais

Cláudia Ulisses

Universidade Federal Rural de Pernambuco

Edson Holanda Teixeira

Universidade Federal do Ceara

Tigressa Helena Soares Rodrigues

Universidade Federal do Ceara

Hélcio Silva Santos

Universidade Estadual Vale do Acarau

Josiani Felix de Souza

Universidade do Estado do Rio Grande do Norte

Maria Daniela Freitas

Universidade do Estado do Rio Grande do Norte

Cynthia Cavalcanti de Albuquerque

Universidade do Estado do Rio Grande do Norte

\section{Research Article}

Keywords: Lippia, salinity, fish farming, antioxidant system, reuse.

Posted Date: May 10th, 2021

DOI: https://doi.org/10.21203/rs.3.rs-442348/v1

License: (c) (i) This work is licensed under a Creative Commons Attribution 4.0 International License. Read Full License 


\section{Abstract}

In order to evaluate the response mechanisms of $L$. gracilis fertigated with saline effluent from fish farming, $L$. gracilis plants were nourished with fish farming effluent with electrical conductivity of $0.45,2.68,4.60,5.55$ and $7.02 \mathrm{dS} \mathrm{m}^{-1}$ for 60 days. The experiment was carried out in the open field using a completely randomized design with five treatments and four replicates. The salinity levels of the nutrient solution containing fish farming effluent did not affect the leaf and stem biomass production, relative water content and leaf area of the studied species. The activity of antioxidant enzymes varied when the nutrient solution salinity level was increased, which also stimulated the breakdown of starch reserves, but did not interfere with the biochemical parameters proline, photosynthetic pigments (chlorophyll a, chlorophyll b and carotenoids), levels of membrane damage and malondialdehyde, indicating that the plant showed no stress symptoms when fertigated with high-salinity effluent. The anatomy of $L$. gracilis leaf cross-sections shows a unistratified epidermis with glandular and non-glandular trichomes in the adaxial and abaxial sides. Plants that received only fish farming effluent $\left(7.02 \mathrm{dS} \mathrm{m}^{-1}\right)$ showed a $25 \%$ reduction in the number of xylem bundles in the midrib region, compared to the control. The yield, chemical composition and antimicrobial activity of the essential oil extracted from L. gracilis leaves did not differ between treatments. Thus, the saline effluent from fish farming can be used in the fertigation of $L$. gracilis without compromising plant yield, avoiding environmental contamination with disposal in soil and/or water bodies.

\section{Highlights}

Salt stress does not affect the morphophysiological properties and biochemical composition of Lippia gracilis;

gracilis has a considerable capacity to withstand high loads of toxic ions, along with maintaining a positive growth rate;

gracilis can be a potential candidate to be considered for use in saline environments

\section{Introduction}

Due to the low availability of surface water in arid and semi-arid areas, it is necessary to use technologies of coexistence based on sustainable water management, especially in agriculture. Among these technologies, the reuse of water is a very common practice, and the use of aquaculture effluent stands out because it can be used not only as a source of water, but also in the practice of fertigation, due its contents of nutrients.

Aquaculture activity has grown $87.1 \%$ in the last decade and fish has become the animal protein of greatest human consumption, about $16.7 \%$ higher compared to other meat (beef, pork, sheep and goat) (FAO 2014). In Brazil, according to the Brazilian Association of Fish Farming (Associação Brasileira de Psicicultura), fish production reached 722,500 tons in 2018 , with tilapia (Oreochromis niloticus) being the fish most frequently produced in breeding tanks.

It is worth pointing out that this activity consumes a lot of water, demanding about $143.7 \mathrm{~m}^{3} /$ ha every day due to the infiltration and evaporation of the breeding nurseries. For the production of one ton of fish, a water demand from 50 to $740,000 \mathrm{~m}^{3}$ is estimated (Oliveira and Santos 2011 ). In the fish harvesting process, the amount of effluent is equally high and its improper disposal in water bodies can cause eutrophication and reduce and change biodiversity (Henry-Silva and Camargo 2009).

In semi-arid environments, water is a natural resource of extreme importance, mainly due to its role in agricultural development, which highlights the need for developing strategies that enable the use of effluents rich in dissolved organic and inorganic compounds that can be used for the benefit of plant nutrition, ensuring efficient and low-cost irrigation. However, this type of water from fish farming is usually saline and, depending on the management, can hamper crop growth and production. The selection of salinity-tolerant species is the main practice used to ensure profitable crops when the goal is to take advantage of saline effluents as a water and nutritional source for agricultural crops and, when there is availability, the effluent can also be diluted to reduce electrical conductivity and attenuate salt stress (Dantas et al. 2019).

Saline effluents can be used to stimulate some plant species to produce bioactive compounds, according to some reports in the literature, which describe that plants irrigated or nourished with saline effluent are stimulated to produce secondary metabolites as a mechanism of defense and adaptation to the saline medium. Species belonging to the genus Lippia stand out in the production of bioactive molecules, since most of them produce a large amount of essential oils with proven antimicrobial properties (Albuquerque et al. 2006; Fernandes et al. 2015), hence being of pharmacological interest. Published studies with L. gracilis mainly cover the effects of the oil and its properties, but the records about the influence of abiotic stresses on oil composition and yield are still scarce. In addition, the studies are limited to controlled environments, which do not reflect the actual behavior of the plant grown in the open field.

As the species focused on in the study produces an essential oil with antimicrobial property and has shown tolerance to salinity in studies conducted in greenhouse (Ragagnin et al. 2013; Oliveira et al. 2019), it is important to enable its planting using saline effluent and/or in areas already salinized. The use of this native species of the Caatinga that is tolerant to salinity and maintains its chemical compounds potentially active opens perspectives to offer a product that can be marketed in the chemical industries, especially in pharmaceutical industries. In addition, it contributes to local economic development, especially in soils that are naturally saline or salinized of the Northeastern semi-arid region. Thus, the objective was to evaluate the response mechanisms of $L$. gracilis as a function of irrigation with the saline effluent from fish farming. 


\section{Materials And Methods}

\subsection{Cultivation conditions, experimental design and irrigation water quality}

The experiment was conducted in an experimental area of $90 \mathrm{~m}^{2}$ belonging to the Center for Environmental Sciences of the Federal Rural University of the Semi-Arid Region - UFERSA, Mossoró - RN, Brazil (5¹2'02.4"S; 37¹9'37.3"W). Four-month-old L. gracilis seedlings were transplanted to 40-cm-deep planting holes, with spacing of $1.0 \mathrm{~m}$ between plants and between rows. During the period of acclimation to the field conditions, about 90 days, the seedlings were irrigated daily with public-supply water from the Water and Sewage Company of Rio Grande do Norte (CAERN).

\subsection{Plant material, growth conditions, and treatments}

At three months after planting, the seedlings were fertigated with a nutrient solution containing public-supply water and saline effluent from tilapia (Oreochromis niloticus Linnaeus) growing nurseries at different concentrations and with different physical-chemical compositions (Table 1 ).

Table 1

Physical-chemical composition of fish farming effluent (FFE) and public-supply water (PSW) used in the experiment. Mossoró-RN, 2018.

\begin{tabular}{|c|c|c|c|c|c|c|c|c|c|c|}
\hline & $\mathrm{pH}$ & EC & KD & $\mathrm{NaX}$ & $\mathrm{Ca}^{2} \boldsymbol{\mathrm { C }}$ & $\mathrm{Mg}^{2} \rrbracket$ & $\mathrm{ClV}$ & $\mathrm{COQ}^{2} \boldsymbol{}$ & HCOQ⿴囗十⺝ & SAR \\
\hline & Água & $\mathrm{dS} / \mathrm{M}$ & \multicolumn{8}{|c|}{$\longrightarrow$ mmolc/L } \\
\hline FFE & 7.30 & 7.02 & 2.0 & 44.91 & 15.10 & 25.70 & 52.80 & 0.00 & 3.80 & 9.9 \\
\hline PSW & 7.0 & 0.5 & 0.25 & 4.44 & 1.00 & 0.90 & 2.4 & 0.00 & 3.40 & 4.6 \\
\hline
\end{tabular}

Fertigation was performed daily in order to maintain the soil field capacity previously established in laboratory tests. The plants were fertigated with a solution containing effluent + public-supply water in different proportions, which were added until reaching the following levels of electrical conductivity (ECs): $452 \mu \mathrm{S}$ (control - T1); $2.68 \mathrm{dS} \mathrm{m}^{-1}$ (T2), $4.60 \mathrm{dS} \mathrm{m}^{-1}$ (T3), $5.55 \mathrm{dS} \mathrm{m}^{-1}$ (T4) and $7.02 \mathrm{dS} \mathrm{m}^{-1}$ (T5), measured with a digital conductivity meter (Soil Control, Inc.). The solutions prepared for fertigation were stored in $500 \mathrm{~L}$ tanks, in the experimental area of $17.5 \mathrm{~m}^{2}$. The experimental design was in randomized blocks, in a total of 5 blocks, each containing 2 sub-plots of each treatment.

Soil water retention curve was used to estimate the water demand of the crop and establish a daily management of the volume of irrigation solution applied, and the daily tension was estimated based on readings of tensiometers installed up to $30 \mathrm{~cm}$ deep in each experimental plot, allowing the calculation of volume of solution to be applied daily in each experimental plot. Based on the soil water retention curve, the tension at field capacity was fixed at $6 \mathrm{KPa}$ (60 cm.w.c.), corresponding to the moisture at FC at $0.1456 \mathrm{~cm}^{3} \mathrm{~cm}^{-3}$. The soil water retention curve for the depths considered was constructed according to the methodology described by Richards (1947), adjusted by the model of Van Genuchten (1980).

The soil of the experimental area was characterized as Oxisol, and disturbed and undisturbed samples were collected in the layers of $0-15 \mathrm{~cm}, 15-30$ $\mathrm{cm}$ and $30-45 \mathrm{~cm}$ for physical-chemical characterization, performed at the Soil Physics Laboratory and at the Irrigation and Salinity Laboratory of the Federal Rural University of the Semi-arid Region - UFERSA (Table 2).

Table 2

Chemical characteristics of the soil of the experimental area used in the experiment. Mossoró - RN, 2018.

\begin{tabular}{|c|c|c|c|c|c|c|c|c|c|c|c|c|c|c|c|c|}
\hline \multirow[t]{2}{*}{ Samples } & $\mathrm{pH}$ & EC & OM & $P$ & $\mathrm{~K}^{+}$ & $\mathrm{Na}^{+}$ & $\mathrm{Ca}^{2+}$ & $\mathrm{Mg}^{2+}$ & $\mathrm{Al}^{3+}$ & $\stackrel{(\mathrm{H}+}{\mathrm{Al})}$ & SB & $t$ & CEC & V & $\mathrm{m}$ & PES \\
\hline & (água) & $\mathrm{ds} / \mathrm{m}$ & $\mathrm{g} / \mathrm{kg}$ & \multicolumn{3}{|c|}{$\mathrm{mg} / \mathrm{dm}^{3}$} & \multicolumn{6}{|c|}{$\mathrm{cmolc} / \mathrm{dm}^{3}$} & \multicolumn{4}{|c|}{$\%$} \\
\hline $\begin{array}{l}0-15 \\
\mathrm{~cm}\end{array}$ & 8.16 & 132.10 & - & 6.0 & 82.2 & 98.9 & 2.20 & 1.97 & 0.00 & 0.00 & 4.81 & 4.81 & 4.81 & 100 & 0 & 9 \\
\hline $\begin{array}{l}15-30 \\
\mathrm{~cm}\end{array}$ & 8.00 & 127.80 & - & 5.5 & 60.6 & 74.6 & 1.20 & 0.55 & 0.00 & 0.00 & 2.23 & 2.23 & 2.23 & 100 & 0 & 15 \\
\hline $\begin{array}{l}30-45 \\
\mathrm{~cm}\end{array}$ & 8.10 & 182.60 & - & 5.6 & 76.8 & 978.2 & 1.58 & 0.92 & 0.00 & 0.00 & 6.95 & 6.95 & 6.95 & 100 & 0 & 61 \\
\hline
\end{tabular}

\subsection{Variables analyzed}

\subsubsection{Physiological and growth analyses}

After 60 days of experiment, the plants were harvested and transported to the Laboratory of Plant Physiology and Biochemistry for growth, biochemical and anatomical analyses. Of the total plants of each treatment, 5 samples were used for growth analyses and 5 were used for the other analyses. Liquid nitrogen was used for cryopreservation of samples intended for biochemical analyses.

To obtain dry mass, the harvested material was washed, separated into stem and leaves, placed on Kraft paper and dried in a forced air circulation oven at $70^{\circ} \mathrm{C}$, until reaching constant weight. Leaf area was measured at the end of the experiment through images analyzed by Image $\mathrm{J}$ software. For this 
variable, branches were collected from the middle region of the plant, placed in refrigerated container and taken to the laboratory for the reading procedure.

To evaluate the relative water content (RWC), one branch was collected from the central region of five plants in each treatment, placed in ice and transported to the laboratory. Three discs of known diameter were removed from the leaves, with a cork borer. The discs were immediately weighed on an analytical scale to determine their fresh mass and then placed in a Petri dish on filter paper soaked with distilled water. The Petri dishes were placed in B.O.D chamber at $25^{\circ} \mathrm{C}$ and $80 \%$ relative humidity, in the dark for $24 \mathrm{~h}$. After this period, the discs were weighed again to determine the turgid mass and soon after they were placed in the oven for drying until reaching constant weight. Dry mass was then determined, and RWC was calculated using the following equation:

$\mathrm{RWC}=\mathrm{FM}-\mathrm{DM} / \mathrm{TM}-\mathrm{DM} \times 100$

Where:

$F M=$ fresh mass

TM = Turgid mass;

DM = Dry mass.

\subsection{Sodium and potassium analyses}

The extracted and exported contents of potassium $(\mathrm{K})$ and sodium $(\mathrm{Na})$ were determined in roots, stems and leaves after opening the flowers of each material. All plants of the plot were collected, then oven dried at $60^{\circ} \mathrm{C}$ and ground in a knife mill. In the extracts obtained by digestion with sulfuric acid, the element $\mathrm{K}$ was determined. The element $\mathrm{Na}$ was extracted with nitric acid. $\mathrm{Na}$ and $\mathrm{K}$ contents were determined by flame emission photometry. Total $\mathrm{N}$ content was determined by the Nessler colorimetric method, after the samples were digested with concentrated $\mathrm{H}_{2} \mathrm{SO}_{4}$. The chemical analyses of the nutrient contents were carried out at the Soil and Plant Laboratory (LASAP), belonging to UFERSA. The ionic ratios were determined by the K/Na ratio of roots, stems and leaves.

\subsection{Biochemical analyses}

The percentage of membrane integrity was estimated from electrolyte leakage (adapted from Azevedo et al., 2008). Five leaf discs with known diameter remained immersed in test tubes with $20 \mathrm{~mL}$ of water for 24 hours at $25^{\circ} \mathrm{C}$. After this period, free electrical conductivity (R1) was measured with a portable conductivity meter. Then, the test tubes were placed in a water bath for one hour at $100^{\circ} \mathrm{C}$ to perform the second reading of electrical conductivity (R2). The percentage of membrane damage (MD) was estimated by the equation: \%MD = (R1/R2) x 100. Membrane damage data were then used to calculate the absolute integrity percentage (AIP) with the equation AIP = 1-R1/R2 and relative integrity percentage (RIP), which corresponds to the ratio between the AIP of plants under stress and the AIP of plants in the control treatment.

Lipid peroxidation was determined according to Heath and Packer (1968), with modifications. The reaction was determined by the production of MDA, a metabolite reactive to 2-thiobarbituric acid (TBA), from readings performed in spectrophotometer at 535 and $600 \mathrm{~nm}$. Plant tissue was macerated in $0.1 \%$ trichloroacetic acid (TCA) along with $20 \%$ polyvinylpolypyrrolidone (PVPP). The samples were homogenized and centrifuged at $10,000 \mathrm{~g}$ for five minutes at a temperature of $4{ }^{\circ} \mathrm{C}$. A $0.25-\mathrm{mL}$ aliquot was collected from the supernatant and transferred to a 1.0-mL Eppendorf tube with solution containing $0.5 \%$ of TBA and $20 \%$ TCA. The solution was put in a water bath $\left(95^{\circ} \mathrm{C}\right)$ for 30 minutes and then cooled for 10 min. Prior to the reading, the samples were centrifuged again for more 10 minutes at $10,000 \mathrm{~g}$.

Hydrogen peroxide $\left(\mathrm{H}_{2} \mathrm{O}_{2}\right)$ was measured according to the protocol proposed by Alexieva et al. (2001). Fresh plant material was macerated with $0.1 \%$ trichloroacetic acid (TCA) at the ratio of $1 \mathrm{~g} / 10 \mathrm{~mL}$ (p:v). Samples were centrifuged at $11,200 \mathrm{~g}$ for $15 \mathrm{~min}$ at $4^{\circ} \mathrm{C}$. A $200-\mu \mathrm{L}$ aliquot was collected from the supernatant and mixed with $200 \mu \mathrm{L}$ of $100 \mathrm{mM}$ potassium phosphate buffer $(\mathrm{pH} 7.5)$ and $800 \mu \mathrm{L}$ of potassium iodide solution. The samples were kept in ice and in the dark for $60 \mathrm{~min}$. After this period, the samples were taken from the ice and kept at room temperature to stabilize the reaction, with subsequent reading in spectrophotometer at $390 \mathrm{~nm}$.

For the extraction of proteins and determination of soluble protein content, the samples were frozen in liquid nitrogen and then macerated and homogenized with $100 \mathrm{mM}$ potassium phosphate buffer (pH 7.5), $1 \mathrm{mM}$ of EDTA (ethylenediaminetetraacetic acid), $3 \mathrm{mM}$ of DL-dithiothreitol and 20\% of PVPP at temperature of $-4{ }^{\circ} \mathrm{C}$ at the ratio of $1 \mathrm{~g} / 3 \mathrm{~mL}$ (w:v) (Azevedo et al. 1998). The homogenate was centrifuged at $10,000 \mathrm{~g}$ for $30 \mathrm{~min}$ and the supernatant was separated into aliquots and kept stored at $-20^{\circ} \mathrm{C}$ until the determination of the enzymatic activities. The total soluble protein content was determined according to the methodology of Bradford (1976), using BSA (bovine serum albumin) as standard.

The enzymatic activity of superoxide dismutase (SOD) was determined according to Giannopolitis and Ries (1977). This method consists in the inhibition of NBT (nitro blue tetrazolium) by the enzymatic extract, preventing the formation of the chromophore. The sample together with the solution composed of a mixture of $3 \mathrm{~mL}$ of phosphate buffer at $85 \mathrm{mM}(\mathrm{pH} 7.8), 75 \mu \mathrm{M}$ of NBT, $5 \mu \mathrm{M}$ of riboflavin, $13 \mathrm{mM}$ of methionine, $0.1 \mathrm{mM}$ of EDTA and $50 \mu \mathrm{L}$ of enzymatic extract were placed in glass tubes and exposed to white light (fluorescent lamp) in a closed box covered with aluminum foil, to better reflect light throughout the environment, for 5 minutes. After this period, reading was performed in a spectrophotometer at $560 \mathrm{~nm}$. 
The enzymatic activity of catalase (CAT) was determined by the method of Havir and Mchale (1987). The solution was prepared with $1 \mathrm{~mL}$ of $100 \mathrm{mM}$ potassium phosphate buffer at $\mathrm{pH} 7.5$ and $25 \mu \mathrm{L}$ of $1 \mathrm{mM}$ hydrogen peroxide. The reaction was initiated by the addition of $25 \mu \mathrm{L}$ of the sample, monitoring the $\mathrm{H}_{2} \mathrm{O}_{2}$ consumption reaction for $1 \mathrm{~min}$. The reaction was monitored in a spectrophotometer at $240 \mathrm{~nm}$ at temperature of $25^{\circ} \mathrm{C}$.

The enzymatic activity of Ascorbate Peroxidase (APX) was determined according to the method proposed by Nakano and Asada (1981). The reaction medium consisted of $650 \mu \mathrm{L}$ of potassium phosphate buffer at $80 \mathrm{mM}, \mathrm{pH} 7.5,100 \mu \mathrm{L}$ of ascorbate at $5 \mathrm{mM}, 100 \mu \mathrm{L}$ of EDTA at $1 \mathrm{M}, 100 \mu \mathrm{L}$ of $\mathrm{H}_{2} \mathrm{O}_{2}$ at $1 \mathrm{mM}$ and $50 \mu \mathrm{L}$ of protein extract. APX activity was determined by the ascorbate oxidation rate for 60 seconds, in spectrophotometer at $290 \mathrm{~nm}$ at 30 ${ }^{\circ} \mathrm{C}$.

Starch content was determined by the colorimetric method standardized by Appenroth et al. (2010). Fresh plant material was macerated in $18 \% \mathrm{HCl}$ $(\mathrm{w} / \mathrm{v})$, incubated at $5{ }^{\circ} \mathrm{C}$ for 1 hour. Then, the suspension was centrifuged at $6682 \mathrm{rpm}$ for 20 minutes. An aliquot of the supernatant was added to another aliquot with equal volume of Lugol's solution $[0.5 \% \mathrm{KI}(\mathrm{w} / \mathrm{v})$ and $0.25 \% \mathrm{I} 2 \mathrm{(w/v})$ in distilled water] to determine absorbance at 530 and $605 \mathrm{~nm}$. The absorbance values were applied in the equation described to determine the starch content.

Reducing sugars were determined using the 3,5-Dinitrosalicilic (DNS) colorimetric method, described by Miller (1959), using in the analysis 250 mg of the samples, diluted in water and mixed with the DNS reagent. The mixture was kept under heating in a water bath at $100^{\circ} \mathrm{C}(\mathrm{boiling})$ for 5 minutes, then cooled with ice bath, to determine the absorbance of the compound formed, at $540 \mathrm{~nm}$. The standard curve of the spectrophotometric determination of reducing sugars was prepared with standards of $1 \mathrm{~g} \cdot \mathrm{L}^{-1}$ of glucose.

Proline content was determined according to the method proposed by Bates et al. (1973). Proline was extracted from $0.3 \mathrm{~g}$ of leaf sample crushed in porcelain crucible with $10 \mathrm{~mL}$ of $3 \%$ sulfosalicylic acid. The reaction mixture was extracted with $5.0 \mathrm{~mL}$ of toluene and stirred for $15 \mathrm{~s}$ in vortex mixer. The tubes were kept for $20 \mathrm{~min}$ in the dark at room temperature to allow separation of the aqueous phase from the toluene. The toluene phase was collected, and absorbance was measured at $520 \mathrm{~nm}$ in spectrophotometer.

\subsection{Anatomical analysis}

For the morphoanatomical evaluation of the median region of L. gracilis leaf blade, slides were prepared from plant material fixed in FAA 70 solution and stored in 70\% alcohol. Leaf segments were dehydrated in alcoholic series and included in paraffin (Johansen, 1940). The cuts (5 $\mu \mathrm{m})$ were performed in a manual rotary microtome (Lupetec®, MRP09 model), stained in a solution of safranin and alcian blue (Bukatsch, 1972) and mounted in Entellan®. After that, the slides were photographed under Top Light B2 optical microscope (Bel®, video microscope). Quantitative analyses were performed using the ImageJ program (Schneider et al., 2012). Tukey test was applied at 5\% probability level using the program Sisvar 5.6 (Ferreira, 2011).

\subsection{Extraction of essential oils}

$390.9 \mathrm{~g}(\mathrm{~T} 1), 562.2 \mathrm{~g}$ (T2), $338.1 \mathrm{~g}$ (T3), $642.8 \mathrm{~g}$ (T4) and $4743 \mathrm{~g}$ (T5) of fresh L. gracilis leaves were subjected to hydrodistillation in a Clevenger-type apparatus for 2 hours to yield $2.13,1.54,1.67,1.95$ and $1.87 \%(w / w)$, respectively. The yields $(\mathrm{w} / \mathrm{w})$ were calculated based on the fresh weight of the plant materials. After being filtered and dried over anhydrous sodium sulfate, the isolated oils were stored in sealed glass vials, which were maintained under refrigeration before analysis.

\subsection{Gas Chromatography-Flame Ionization Detection}

GC-FID for the quantitative analysis was carried out on a Shimadzu GC-17A gas chromatograph using a dimethylpolysiloxane DB-5 fused silica capillary column (30 mm x $0.25 \mathrm{~mm}, 0.25 \mathrm{~m}$ film thickness). $\mathrm{H}_{2}$ was used as the carrier gas at a flow rate of $1 \mathrm{~mL} / \mathrm{min}$ and $30 \mathrm{psi}$ inlet pressure; split, 1:30; temperature program: $35-180^{\circ} \mathrm{C}$ at $4^{\circ} \mathrm{C} / \mathrm{min}$, then heated at a rate of $17^{\circ} \mathrm{C} / \mathrm{min}$ to $280^{\circ} \mathrm{C}$ and held isothermal for $10 \mathrm{~min}$; injector temperature: $250^{\circ} \mathrm{C}$; detector used: FID, detector temperature: $250^{\circ} \mathrm{C}$.

\subsection{Gas Chromatography-Mass Spectrometry}

GC-MS for the analysis of the volatile constituents was carried out on a Hewlett-Packard 5971 GC/MS using a non-polar DB-5 fused silica capillary column (30 mm x $0.25 \mathrm{~mm}$ i.d., $0.25 \mathrm{~m}$ film thickness); carrier gas: helium, with flow rate of $1 \mathrm{~mL} / \mathrm{min}$ and split ratio of $1: 1$. The injector temperature and detector temperature were $250^{\circ} \mathrm{C}$ and $200^{\circ} \mathrm{C}$, respectively. Column temperature was programmed from $35^{\circ} \mathrm{C}$ to $180{ }^{\circ} \mathrm{C}$ at $4{ }^{\circ} \mathrm{C} / \mathrm{min}$ and then from $180^{\circ} \mathrm{C}$ to $250^{\circ} \mathrm{C}$ at $10^{\circ} \mathrm{C} / \mathrm{min}$. Mass spectra were recorded from $30-450 \mathrm{~m} / \mathrm{z}$. Individual components were identified by matching their 70 eV mass spectra with those of the spectrometer database through the Wiley L-built library MS searches using retention indices as a preselection routine.

\subsection{Antibacterial activity}

The antimicrobial activity of the essential oil extracted from the leaves of $L$. gracilis under different salinity treatments was evaluated using the microdilution method according to the Clinical \& Laboratory Standards Institute (CLSI 2017), with modifications described by Vale et al. (2019). Grampositive bacteria Staphylococcus aureus ATCC 25923, Staphylococcus aureus ATCC 700698, Staphylococcus epidermidis ATCC 12228 and Staphylococcus epidermidis ATCC 35984, and Gram-negative bacteria Escherichia coli ATCC 11303 and Pseudomonas aeruginosa ATCC 10145 were used. 
Initially, $100 \mu \mathrm{L}$ of each essential oil, solubilized in Tryptone Soya Broth (TSB; Liofilchem, Italy), were added to the wells of the microtitration plates at concentrations ranging from 5 to $0.04 \%$, and then $100 \mu \mathrm{L}$ of bacterial suspension $\left(1 \times 10^{6} \mathrm{CFU} / \mathrm{mL}\right)$ were added to the wells. The plate was incubated for $24 \mathrm{~h}$ at $37^{\circ} \mathrm{C}$ and later the optical density of each well was measured at $620 \mathrm{~nm}$ wavelength with a microplate reader (SpectraMax i3).

The lowest concentration of essential oil capable of visually inhibiting bacterial growth was considered as MIC. For the determination of MBC, $10 \mu \mathrm{L}$ of the solution contained in the wells that did not have microbial growth were collected, followed by inoculation in Petri dishes with Tryptone Soya Agar medium (TSA; Liofilchem, Italy) and subsequent incubation for $24 \mathrm{~h}$ at $37^{\circ} \mathrm{C}$. After the 24 -hour period, the presence of colony-forming units (CFU) was evaluated and the lowest concentration of essential oil that inhibited the growth of CFUs on the plates was considered as the MBC.

\subsection{Experimental design and statistical analysis}

The experimental design was completely randomized (CRD) with five treatments (levels of electrical conductivity) and 10 replicates per treatment. After the experimental period, the plants were collected and subjected to analysis, 5 replicates per treatment for growth and nutrition analyses and 5 replicates per treatment for biochemical, anatomical and oil yield analyses. The samples for biochemical analyses were frozen in liquid $\mathrm{N}$ and kept in a vertical freezer at $-30^{\circ} \mathrm{C}$. The data obtained were subjected to analysis of variance and the means were compared by Tukey test at $5 \%$ probability level, expressed as mean and standard deviation of the mean (Mean $\pm S D, n=3$ ). The statistical analysis was performed using the program ASSISTAT, beta version 7.6 (Silva, 2015).

\section{Results}

\subsection{Biomass, osmoregulators and pigments}

The addition of fish farming effluent in irrigation water did not significantly influence $(p<0.05)$ leaf dry biomass, stem dry biomass and RWC (Table 3 ). Leaf RWC ranged from 64 to $72 \%$ on average. In general, the plants of all treatments showed vigorous appearance, with no signs of damage or senescence.

Table 3

Effect of fish farming effluent on leaf dry biomass (LDB), stem dry biomass (SDB), relative water content (RWC) and final leaf area (FLA) of L. gracilis plants.

\begin{tabular}{|lllll|}
\hline Treatments & LDB $(\mathbf{m g})$ & SDB $(\mathbf{m g})$ & RWC $(\%)$ & FLA $\left(\mathbf{c m}^{3}\right)$ \\
\hline T1 & $67.17 \pm 2.99 \mathrm{a}$ & $159.13 \pm 4.18 \mathrm{a}$ & $67.24 \pm 1.51 \mathrm{a}$ & $5.487 \pm 337 \mathrm{a}$ \\
\hline T2 & $69.52 \pm 4.38 \mathrm{a}$ & $169.30 \pm 9.34 \mathrm{a}$ & $68.80 \pm 1.82 \mathrm{a}$ & $5.296 \pm 178 \mathrm{a}$ \\
\hline T3 & $61.97 \pm 3.13 \mathrm{a}$ & $160.70 \pm 4.74 \mathrm{a}$ & $68.95 \pm 0.63 \mathrm{a}$ & $4.752 \pm 349 \mathrm{a}$ \\
\hline T4 & $71.21 \pm 4.14 \mathrm{a}$ & $175.60 \pm 9.35 \mathrm{a}$ & $71.65 \pm 1.85 \mathrm{a}$ & $4.986 \pm 356 \mathrm{a}$ \\
\hline T5 & $69.95 \pm 2.93 \mathrm{a}$ & $186.33 \pm 8.03 \mathrm{a}$ & $71.76 \pm 0.82 \mathrm{a}$ & $5.897 \pm 657 \mathrm{a}$ \\
\hline CV\% & 26.86 & 20.29 & 7.59 & 17.76 \\
\hline (T1=452 $\mu$; $2.68 \mathrm{dS}$ m-1; T2=4.60 dS m-1; T3= 5.55 dS m-1; T4=5.55 dS m-1; and T5=7.02 dS m-1). \\
\hline Means followed by the same letters do not differ statistically by Tukey test at 5\% probability level. \\
\hline
\end{tabular}

Data of chloroplast pigments indicate that the photochemical apparatus was not damaged by the variation in electrical conductivity (Table 4), which is considered important for the development of plants subjected to abiotic stress.

Table 4

Effect of fish farming effluent on chlorophyll a, chlorophyll b, total chlorophyll and carotenoids (mg $\mathrm{g}^{-1}$ fresh mass) of L. gracilis plants.

\begin{tabular}{|lllll|}
\hline $\begin{array}{l}\text { Treatments } \\
\text { (mg.g }\end{array} \mathbf{~}^{-1}$ fresh mass) & Chlorophyll a & Chlorophyll b & Total chlorophyll & Carotenoids \\
\hline T1 & & & & \\
\hline T2 & $0.469 \pm 0.01 \mathrm{a}$ & $0.717 \pm 0.10 \mathrm{a}$ & $1.181 \pm 0.09 \mathrm{a}$ & $302.00 \pm 14.83 \mathrm{a}$ \\
\hline T3 & $0.454 \pm 0.01 \mathrm{a}$ & $0.569 \pm 0.02 \mathrm{a}$ & $1019 \pm 0.02 \mathrm{a}$ & $288.92 \pm 4.27 \mathrm{a}$ \\
\hline T4 & $0.320 \pm 0.05 \mathrm{a}$ & $0.611 \pm 0.07 \mathrm{a}$ & $0.927 \pm 0.06 \mathrm{a}$ & $302.71 \pm 33.98 \mathrm{a}$ \\
\hline T5 & $0.442 \pm 0.02 \mathrm{a}$ & $0.523 \pm 0.04 \mathrm{a}$ & $0.962 \pm 0.03 \mathrm{a}$ & $269.49 \pm 12.36 \mathrm{a}$ \\
\hline CV\% & $0.313 \pm 0.01 \mathrm{a}$ & $0.577 \pm 0.03 \mathrm{a}$ & $0.886 \pm 0.06 \mathrm{a}$ & $283.47 \pm 4.00 \mathrm{a}$ \\
\hline
\end{tabular}

$\left(\mathrm{T} 1=452 \mu \mathrm{S} ; 2.68 \mathrm{dS} \mathrm{m}^{-1} ; \mathrm{T} 2=4.60 \mathrm{dS} \mathrm{m}^{-1} ; \mathrm{T}_{3}=5.55 \mathrm{dS} \mathrm{m}^{-1} ; \mathrm{T} 4=5.55 \mathrm{dS} \mathrm{m}^{-1} ;\right.$ and T5=7.02 dS m-1). 
Means followed by the same letters do not differ statistically by Tukey test at $5 \%$ probability level.

\subsection{Osmoregulation}

The levels of reducing sugars differed as a function of the salinity of the fish farming effluent. In treatments 2 and 3 , higher sugar production was observed; while at the highest salinity, sugar levels were lower (Fig. 1A). On the other hand, when the salinity levels of the effluent increased, the starch content decreased progressively, with reductions ranging from 37 to $19 \%$ in the control and T5 treatments, respectively (Fig. 1B). On the other hand, the content of proline, an important osmoregulator in stress situations, was statistically lower only at the highest salt level (Fig. 1C).

\subsection{Ion concentrations in stem, leaves and roots}

The $\mathrm{Na}^{+}$and $\mathrm{K}^{+}$levels differed between the different salt concentrations of the fish farming effluent. It is observed that $\mathrm{K}$ levels were higher in leaves than in the other organs. Despite the increase in salt concentration, T5 did not differ statistically from the control. The roots showed lower concentrations of this macronutrient, even in the control treatment (Fig. 2A, B and C). On the other hand, sodium was more significantly concentrated in the stem, but in the treatment with highest salinity, this element remained concentrated in the leaves (Fig. $2 \mathrm{~B}$ ). The $\mathrm{Na}^{+} / \mathrm{K}^{+}$ratio confirms that plants tend to accumulate sodium in the stem, contributing to stress modulation; however, at higher levels of salinity, sodium was translocated to the leaves (Fig. 2C), probably as a defense strategy, through leaf senescence.

\subsection{Oxidative Stress}

No increments were detected in the percentage of membrane damage in the leaf tissues of $L$. gracilis, also accompanied by the maintenance of the content of malondialdehyde (MDA), a product of the peroxidation of polyunsaturated fatty acids of biomembranes (Fig. $3 \mathrm{~A}$ and $\mathrm{B}$ ). However, there was an increase in $\mathrm{H}_{2} \mathrm{O}_{2}$ levels with significant increments $(p<0.05)$ at all salinity levels of the effluent compared to the control.

The antioxidant enzymatic system, represented by the activity of the enzymes SOD, APX and CAT, showed significant differences with the salinity of the fish farming effluent. It was possible to observe maintenance of SOD activity, generating $\mathrm{H}_{2} \mathrm{O}_{2}$, in parallel with an increase in APX and/or CAT. These antioxidant responses were sufficient to maintain MDA levels in all treatments (Fig. 4). The observed increase in $\mathrm{H}_{2} \mathrm{O}_{2}$ content suggests the generation of this ROS from other metabolic processes.

\subsection{Anatomy}

The cross-sections of L. gracilis leaves show a unistratified epidermis with glandular and non-glandular trichomes in the adaxial and abaxial sides. The mesophyll is dorsiventral, with the palisade parenchyma involving the vascular system, which has a half-moon shape in the leaf midrib (Fig. 5). In addition, the presence of raphides in parenchyma cells was verified, suggesting the presence of a calcium-rich compound, probably oxalate, in all treatments evaluated (Fig. $5 \mathrm{~F}$ and $\mathrm{P}$ ).

The number of auxiliary vessels (NAV) in the leaves of plants subjected to different concentrations of the effluent did not differ between the treatments tested (Table 5). In this respect, plants that received only fish farming effluent (T5) showed a $25 \%$ reduction in the number of xylem bundles in the midrib region when compared to plants of the control treatment (Table 5). To compensate for this reduction, there was an increase of about $171 \%$ in the number of xylem vessels in the leaves of plants irrigated with different combinations of fish farming effluent. In addition, the use of effluent was related to the apparent increase in the lignification of xylem cells, which were identified by wall thickening and intensification of safranin staining (Figs. $6 \mathrm{~B}$, $\mathrm{E}$, $\mathrm{H}, \mathrm{K})$.

Table 5

Effect of fish farming effluent on the mean number of xylem bundles (NXB), number of xylem vessels (NXV), number of auxiliary vessels (NAV) and mesophyll thickness (MT) in L. gracilis leaves.

\begin{tabular}{|lllll|}
\hline Treatments & NXB $\left(\mathrm{mm}^{2}\right)$ & NXV $\left(\mathrm{mm}^{2}\right)$ & NAV $\left(\mathrm{mm}^{2}\right)$ & MT $(\mu \mathrm{m})$ \\
\hline T1 & $20.0 \pm 1.2 \mathrm{a}$ & $2.8 \pm 0.1 \mathrm{~d}$ & $3.0 \pm 0.3 \mathrm{a}$ & $194.222 .7 \pm 9.8 \mathrm{a}$ \\
\hline T2 & $16.3 \pm 1.8 \mathrm{ab}$ & $3.7 \pm 0.3 \mathrm{c}$ & $3.0 \pm 0.3 \mathrm{a}$ & $194.222 .7 \pm 12.5 \mathrm{a}$ \\
\hline T3 & $15.3 \pm 0.9 \mathrm{ab}$ & $5.6 \pm 0.1 \mathrm{~b}$ & $3.3 \pm 0.0 \mathrm{a}$ & $203.333 .0 \pm 12.5 \mathrm{a}$ \\
\hline T4 & $15.3 \pm 3.0 \mathrm{ab}$ & $7.5 \pm 1.4 \mathrm{a}$ & $3.3 \pm 0.3 \mathrm{a}$ & $205.357 .7 \pm 9.1 \mathrm{a}$ \\
\hline T5 & $15.0 \pm 3.1 \mathrm{~b}$ & $76 \pm 1.1 \mathrm{a}$ & $4.3 \pm 0.3 \mathrm{a}$ & $209.143 .0 \pm 11.3 \mathrm{a}$ \\
\hline CV\% & 11.24 & 6.25 & 18.6 & 9.58 \\
\hline (T1=452 $\mu$; $2.68 \mathrm{dS} \mathrm{m}^{-1} ; \mathrm{T} 2=4.60 \mathrm{dS}$ m-1; T3= 5.55 dS m-1; T4=5.55 dS m-1; and T5=7.02 dS m-1). \\
\hline Means followed by the same letters do not differ statistically by Tukey test at 5\% probability level.
\end{tabular}

\subsection{Essential oil composition analysis}

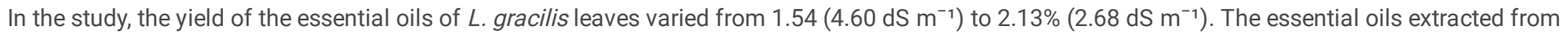
L. gracilis leaves were analyzed by GC/MS and GC/FID, and the constituents were identified and quantified (Table 6). A total of 25 compounds

Page $7 / 18$ 
organized in order of elution in a DB-5 column were identified in the five essential oil samples. The chemical composition of the essential oil from $L$. gracilis is mostly constituted by monoterpenes, phenylpropanoids and sesquiterpenes. The major components are: carvacrol (45.35 to $50.17 \%$ ) (1), pcymene (14.16 to $16.81 \%$ ) (2) and $y$-terpinene (12.44 to 15.03\%) (3) (Fig. 6). Moreover, the results showed that the variations in water salinity did not cause significant difference in oil yield per plant, between the five plant samples (Table 6).

Table 6

Chemical composition of essential oils from the leaves of L. gracilis irrigated with fish farming effluent with different levels of salinity.

\begin{tabular}{|c|c|c|c|c|c|c|c|}
\hline & \multirow{2}{*}{$\mathrm{IK}_{\mathrm{calc}}{ }^{1}$} & \multirow{2}{*}{$\mathrm{IK}_{\text {lit }}^{2}$} & \multicolumn{5}{|l|}{$\%$} \\
\hline & & & T1 & T2 & T3 & T 4 & T5 \\
\hline Leaf oil yield / \% & & & 2.13 & 1.54 & 1.67 & 1.95 & 1.87 \\
\hline Water salinity / dS m¹ & & & 2.68 & 4.60 & 5.55 & 7.02 & 7.02 \\
\hline \multicolumn{8}{|l|}{ Leaf oil constituent / \% } \\
\hline a-Thujene & 933 & 930 & 1.09 & 1.23 & 1.34 & 1.56 & 1.48 \\
\hline a-Pinene & 942 & 932 & 0.24 & 0.26 & 0.29 & 0.34 & 0.32 \\
\hline$\beta$-Pinene & 985 & 979 & & 0.07 & 0.07 & 0.08 & 0.08 \\
\hline$\beta$-Myrcene & 993 & 990 & 1.25 & 1.33 & 1.40 & 1.54 & 1.60 \\
\hline a-Phellandrene & 1011 & 1002 & 0.19 & 0.17 & 0.18 & 0.20 & 0.19 \\
\hline$\Delta$-3-Carene & 1017 & 1011 & & 0.11 & 0.12 & 0.12 & 0.13 \\
\hline a -Terpinene & 1023 & 1017 & 1.94 & 2.12 & 2.13 & 2.38 & 2.31 \\
\hline$p$-Cymene & 1031 & 1024 & 14.16 & 14.45 & 15.07 & 16.29 & 16.81 \\
\hline Limonene & 1036 & 1029 & 0.34 & 0.35 & 0.37 & 0.40 & 0.40 \\
\hline$\beta$-Ocimene & 1041 & 1037 & 0.24 & 0.24 & 0.23 & 0.24 & 0.24 \\
\hline$\beta$-Ocimene & 1052 & 1050 & 0.12 & 0.14 & 0.14 & 0.15 & 0.15 \\
\hline Y-Terpinene & 1065 & 1059 & 12.44 & 13.77 & 13.57 & 15.03 & 14.47 \\
\hline Ipsdienol & 1151 & 1145 & 0.94 & 1.02 & 0.97 & 0.98 & 0.90 \\
\hline Terpinen-4-ol & 1184 & 1177 & 0.45 & 0.47 & 0.45 & 0.52 & 0.52 \\
\hline Thymol methyl ether & 1240 & 1235 & 2.30 & 0.36 & 0.27 & 0.34 & 0.35 \\
\hline Carvacrol methyl ether & 1244 & 1241 & 2.08 & 0.28 & 0.27 & 0.28 & 0.33 \\
\hline Thymol & 1295 & 1290 & 7.78 & 8.15 & 7.93 & 7.52 & 7.17 \\
\hline Carvacrol & 1306 & 1299 & 48.57 & 50.17 & 48.98 & 45.35 & 46.83 \\
\hline a-Copaene & 1384 & 1376 & & & 0.15 & 0.21 & 0.18 \\
\hline$\beta$-Caryophyllene & 1429 & 1419 & 2.63 & 2.53 & 2.73 & 3.38 & 2.76 \\
\hline a-Caryophyllene & 1464 & 1454 & & & & 0.17 & 0.15 \\
\hline Bicyclogernacrene & 1505 & 1500 & 0.37 & 0.11 & 0.35 & 0.40 & 0.31 \\
\hline $\delta$-Cadinene & 1532 & 1523 & & & 0.13 & 0.17 & 0.14 \\
\hline Spathulenol & 1588 & 1578 & 0.18 & 0.19 & 0.17 & 0.16 & 0.15 \\
\hline Caryophyllene oxide & 1593 & 1583 & 0.56 & 0.51 & 0.56 & 0.50 & 0.54 \\
\hline \multicolumn{3}{|c|}{ Monoterpene hydrocarbon } & 32.01 & 34.24 & 34.91 & 38.33 & 38.18 \\
\hline \multicolumn{3}{|l|}{ Oxygenated monterpene } & 1.39 & 1.49 & 1.42 & 1.5 & 1.42 \\
\hline \multicolumn{3}{|l|}{ Phenylpropanoid } & 60.73 & 58.96 & 57.45 & 53.49 & 54.68 \\
\hline \multicolumn{3}{|c|}{ Sesquiterpene hydrocarbon } & 3.00 & 2.64 & 3.21 & 4.33 & 3,54 \\
\hline \multicolumn{3}{|c|}{ Oxygenated sesquiterpene } & 0.74 & 0.7 & 0.73 & 0.66 & 0,69 \\
\hline \multicolumn{3}{|l|}{ Total } & 97.87 & 98.03 & 97.72 & 98.31 & 98.51 \\
\hline
\end{tabular}




\subsection{Antimicrobial activity}

The antimicrobial activity of the essential oil from leaves of $L$. gracilis irrigated or not with fish farming effluent was tested against clinically relevant bacterial strains. The results showed MIC and MBC of the essential oil against Gram-positive bacteria, with values ranging from 0.625 to $2.5 \%$. Interestingly, E. coli ATCC 11303 showed greater sensitivity to the action of the essential oil. On the other hand, L. gracilis essential oil showed only MIC at $2.5 \%$ against $P$. aeruginosa ATCC 10145 (Table 7).

Table 7

Minimum Inhibitory Concentration (MIC) and Minimum Bactericidal Concentration (MBC) of essential oils extracted from leaves of $L$. gracilis irrigated with fish farming effluent with different salinity levels on Gram-positive and Gram-negative bacteria.

\begin{tabular}{|c|c|c|c|c|c|c|c|c|c|c|}
\hline \multirow[t]{3}{*}{ Strains } & \multicolumn{10}{|c|}{ Essential oil from Lippia gracilis \% (v/v) } \\
\hline & \multirow{2}{*}{$\begin{array}{l}\text { T1* } \\
\text { MIC }\end{array}$} & \multicolumn{2}{|c|}{ T2 } & \multicolumn{2}{|c|}{ T3 } & \multicolumn{2}{|c|}{ T4 } & \multicolumn{2}{|c|}{ T5 } & \multirow[b]{2}{*}{ MBC } \\
\hline & & MBC & MIC & MBC & MIC & MBC & MIC & MBC & MIC & \\
\hline S. aureus ATCC 25923 & 0.625 & 1.25 & 0.625 & 0.625 & 0.625 & 0.625 & 0.625 & 0.625 & 0,625 & 1.25 \\
\hline S. aureus ATCC 700698 & 0.625 & 0.625 & 0.625 & 0.625 & 0.625 & 0.625 & 1.25 & 1.25 & 0.625 & 0.625 \\
\hline S. epidermidis ATCC 12228 & 1.25 & 1.25 & 1.25 & 1.25 & 1.25 & 1.25 & 1.25 & 1.25 & 1.25 & 1.25 \\
\hline S. epidermidis ATCC 35984 & 0.625 & 1.25 & 0.625 & 1.25 & 0.625 & 1.25 & 1.25 & 2.5 & 1.25 & 2.5 \\
\hline E. coli ATCC 11303 & 0.31 & 0.625 & 0.15 & 0.15 & 0.31 & 0.625 & 0.625 & 0.625 & 0.31 & 0.625 \\
\hline P. aeruginosa ATCC 10145 & 2.5 & - & 2.5 & - & 2.5 & - & 2.5 & - & 2.5 & - \\
\hline
\end{tabular}

\section{Discussion}

The exposure of plants to salinity of the fertigation solution induces morphophysiological and biochemical responses that occur through molecular mechanisms (Gupta and Huang 2014), which may alter plant physiology and reduce photosynthesis, growth and leaf area values (Anjum et al. 2011). However, plant tolerance or sensitivity varies between species and between cultivars of the same species, and plant growth and yield are the main parameters for assessing the responses of crops to salt stress (Lei et al. 2014). The proportions of the effluent in the fertigation solution did not influence the growth of $L$. gracilis plants in terms of biomass allocation (Table 3). The results of this study are in line with those found by Oliveira et al. (2019), who worked with the same species irrigated with a solution composed of sodium chloride, dihydrate calcium chloride and hexahydrate magnesium chloride, under greenhouse conditions. With highly saline solutions $\left(9.9 \mathrm{dS} \mathrm{m}^{-1}\right)$, the authors observed a behavior of lower biomass production in leaves and stems.

These different responses between the present study and that conducted by Oliveira et al. (2019) may be linked to the source of salinity used. The effluent from tilapia cultivation has a significant amount of nutrients originated from the feeds used in the diets of fish and animal excretes; possibly, the nutrients added to the soil reduce the deleterious effects of salinity of the saline nutrient solution, especially the effects of chloride and sodium toxicity on the plants, causing them to have greater tolerance to salinity when fertigation is used as a water and nutritional source in the crops. The absence of change in leaf area among the evaluated treatments may be one of the factors that contributed to the maintenance of growth, since in situations of salt stress, plants reduce their leaf area, characterizing a strategy to avoid high transpiration rates, influencing photosynthesis and consequently limiting biomass production (Silveira et al. 2016; Silva et al. 2011).

The maintenance of growth levels, and consequently of biomass, may have been influenced by the maintenance of adequate $\mathrm{K}^{+}$levels in the leaves up to T4. Plants often experience reduction of $\mathrm{K}^{+}$when there is exposure to higher levels of $\mathrm{Na}^{+}$due to the competition of this ion for the absorption channels of other ions, especially with $\mathrm{K}^{+}$(Kibria et al. 2017). However, this result was only observed in the treatment with highest salinity, in which there was a reduction in $\mathrm{K}^{+}$to the detriment of $\mathrm{Na}^{+}$. The $\mathrm{Na}^{+} / \mathrm{K}^{+}$ratio confirms that there was a higher allocation of sodium to the stem in all treatments, except for T5. The mobilization of $\mathrm{Na}^{+}$ions to the stem and the maintenance of adequate levels of $\mathrm{K}^{+}$in the leaves allowed greater protection and functionality of the photosynthetic organs, as well as the growth rate of the plant (Miranda et al. 2017). The change of sodium allocation to the leaves in the treatment of highest salinity can be explained as a strategy of defense of the plant, since the leaves expel sodium when they senesce.

Growth is influenced by salinity and by osmotic imbalance and disturbances in the photosynthetic apparatus and osmoregulation (Negrão et al. 2017). Thus, the water retention capacity in leaf tissues, evaluated in this study by the relative water content (RWC) (Table 3), favored the tolerance to salinity, as it kept the cells turgid, providing full functioning of physiological processes, which positively influences the growth process, as shown in the 
parameters of leaf dry biomass and stem dry biomass (Table 3). The maintenance of RWC levels in L. gracilis subjected to salinity had already been identified by Ragagnin et al. (2014) under greenhouse conditions with different salinity levels.

The maintenance of leaf tissue hydration is a behavior of plants that can adjust osmotically. Thus, some species invest in sugar synthesis or starch breakage in an attempt to mitigate damage caused by stress (Almodares et al. 2008; Santelia and Lawson 2016). In this study, starch contents decreased (Fig. 1B) in treatments with higher salinity levels, indicating that the species was using its polysaccharide reserves to produce sugars for osmoregulation in order to keep leaf tissue hydrated according to its osmotic potential, thus maintaining its metabolism in operation.

In situations of abiotic stress, plants accumulate in the cytosol or vacuoles low-molecular-weight solutes (proline, betaine glycine, sucrose) to maintain water balance and preserve the integrity of membranes, proteins and enzymes (Ashraf et al. 2013; Marijuan and Bosch 2013). However, depending on the intensity and duration of stress, the production of these osmoregulators may or may not be intensified. In this study, it was observed that proline levels decreased at the highest concentrations of the effluent (Fig. 1C). This finding indicates, once again, that sugar production served as the main regulatory mechanism for the maintenance of water potential and leaf tissue turgor. It is important to highlight that in saline treatments with up to 5.5 $\mathrm{dS} \mathrm{m}^{-1}$ the proline levels did not differ from those of the control. It is suggested that this result is probably attributed to the adaptation of $L$. gracilis to environments with water scarcity and high temperatures. Under these conditions, proline is generally produced to keep the tissues hydrated, avoiding stress by desiccation. Results similar to these were found by Hu et al. (2012) in wheat plants, where proline levels decreased when sugar levels were high because, besides acting on osmoregulation, high values of sugar helped the plant to eliminate ROS (Cuoee et al. 2006).

The level of membrane damage measured by electrolyte leakage as a function of electrical conductivity (Munns and Tester 2008) and the contents of malondialdehyde (MDA) are important indicators of oxidative stress. The results obtained in this study do not point to salt stress, indicating that the salinity of the effluent did not increase the peroxidation of unsaturated fatty acids of the membrane of $L$. gracilis, confirming the degree of tolerance of the species under study.

Lipid peroxidation patterns can be modulated according to the amount of ROS generated and the defense capacity of the cells. One of the factors that can increase lipid peroxidation is excessive production and non-removal of $\mathrm{H}_{2} \mathrm{O}_{2}$. This compound is naturally synthesized by plants and its production occurs mainly through photorespiration or as a result of the dismutation of the superoxide radical, by superoxide dismutase (SOD). $\mathrm{H}_{2} \mathrm{O}_{2}$ can react with $\mathrm{Fe}^{2+}$ ions and form hydroxyl radical $(\mathrm{OH})$, a ROS that can peroxide membrane lipids (Sewelam et al. 2016). However, the increase in $\mathrm{H}_{2} \mathrm{O}_{2}$ contents in plants will not always lead to increments in lipid peroxidation and oxidative stress, which can result in enzyme inactivation and limitation in plant growth and development (Gil and Turjeta 2010; De Choudhury et al. 2013). Thus, in order to overcome the negative effects caused by ROS, plants have an enzymatic antioxidant defense system, composed mainly of the enzymes superoxide dismutase (SOD), ascorbate peroxidase (APX) and catalase (CAT) (Sewelam et al. 2016). $\mathrm{H}_{2} \mathrm{O}_{2}$ generated by SOD triggers CAT and APX enzymes, which are responsible for converting $\mathrm{H}_{2} \mathrm{O}_{2}$ into $\mathrm{H}_{2} \mathrm{O}$ and $\mathrm{O}_{2}$. These enzymes act according to their degrees of specificity; the CAT enzyme acts more significantly under conditions of greater severity (for example, T4), as it requires two molecules of $\mathrm{H}_{2} \mathrm{O}_{2}$ for the reaction. On the other hand, the APX enzyme is more sensitive and has the ability to react with only one molecule of $\mathrm{H}_{2} \mathrm{O}_{2}$, hence having lower action under the same conditions (for example, T2). This means that, at the salinity level 4, CAT was the most triggered enzyme to remove $\mathrm{H}_{2} \mathrm{O}_{2}$ compared to APX (Fig. 4). Increase in CAT activity was observed by Gondim et al. (2012) in a study with corn plants subjected to stress induced by $\mathrm{NaCl}$, where the harmful effects of salinity did not compromise the growth variables. This result is indicated by the authors due to the performance of the antioxidant system, especially CAT.

In stressful situations, the content of pigments can be affected by the decrease in biosynthesis or the acceleration of their degradation (Ashraf and Harris 2013). Thus, in an attempt to adjust itself to the salinity and temperature conditions to which it was exposed, this species invested in the production of photosynthetic pigments, such as carotenoids, which act not only in the photosynthetic apparatus, but also as non-enzymatic components of the antioxidant system in the photoprotection and dissipation of energy, thus avoiding the formation of ROS and assisting in combating oxidative stress, consequently decreasing the harmful effects on the photosynthetic apparatus of the plant. The photoprotective effect of carotenoids assists in the dissipation of energy by exposure to high temperature and luminosity (Domonkos et al. 2013), through proteins present in the lumen of the thylakoids (Li et al. 2000).

As for anatomy, the results indicate that the fish farming effluent favored the development of the vascular system by increasing the number of xylem vessels, which is considered as an anatomical adaptation to salinity, aiming to improve the flow of water, since the frequency of xylem vessels and tracheids are determinant for water conductance (Sánchez-Aguayo et al. 2004). In addition to being responsible for long-distance transport of water and solutes, xylem is related to the mechanical support (Costa et al. 2004), preventing cells from collapsing and preventing the harmful effects of cavitation (Eller et al. 2018).

The presence of calcium oxalate crystals is not a common characteristic to all members of the Verbenaceae family (Souza et al. 2005; Braga et al. 2009); however, the presence of these crystals in leaves of other species of the genus Lippia has been documented, being highlighted as a xeromorphic characteristic (Andersen et al. 2006). On the other hand, the maintenance of the number of auxiliary vessels (NAV) in the leaves of plants subjected to different concentrations of fish farming effluent denotes that in plants subjected to treatment with $100 \%$ of fish farming effluent there was no need to invest in the formation of new vascular bundles to optimize the transport of resources. 
The fish farming effluent did not interfere in the water balance of the cells in such a way to hamper the transport of water, so the mesophyll thickness was similar in all treatments evaluated (Table 5; Fig. 5), indicating that there was water maintenance in the cells, since water availability is one of the factors that first affect the maintenance of cell turgor (Santos and Carlesso 1998), which may therefore affect the mesophyll thickness.

Essential oils are components of the secondary metabolism of plants that are extracted from several parts (Oussalah et al. 2007). These compounds guarantee some advantages, acting for example as antioxidants and in the fight against microbial agents (Gutierrez et al. 2008). However, the chemical composition and content of the essential oil of a same species are associated with a variety of factors. According to Morais (2009), genetic traits, age and some climatic and environmental factors can lead to significant changes in the production of secondary metabolites by plants. Depending on the environment in which the plant is located, the salt concentration of the medium and the time of exposure, its metabolic route can be redirected, causing biosynthesis of different compounds and alteration of the content and chemical composition of essential oils (Neffati and Marzouk 2008). The conditions of the growing environment did not alter the chemical composition and content of oil under the conditions evaluated in this study. Similar results for the levels of thymol and carvacrol were found by Albuquerque et al. (2012) and Ragagnin (2014) in plants of the same species.

According to literature reports, conditions of low and high salinity of irrigation water do not interfere with the yield of the essential oil of $L$. gracilis species (Oliveira et al. 2019). Based on the published data, the results obtained showed coherence because the most frequent components to appear in the essential oils of many species of Lippia are limonene, $\beta$-caryophyllene, p-cymene, camphor, linalool, $a$-pinene and thymol (Pascoal et al. 2001).

Chemical composition of L. gracilis essential oils obtained from other states in northeastern Brazil showed that: in Ceará, the essential oil was characterized by thymol (30.6\%) and p-cymene (10.7\%) as major components; in Piauí, there was carvacrol (47.7\%) and p-cymene (19.2\%); and in Sergipe, carvacrol (23.52\%), p-cymene (4) (15.82\%), y-terpinene (14.17\%) and menthol (10.97\%) (Gomes et al. 2011). The quantitative variations observed in the chemical composition of the essential oils of L. gracilis are probably due to genetic factors such as different forms of the trichomes present in different species of Lippia and edaphoclimatic conditions such as climate, relief, lithology, temperature, air humidity, radiation, soil type, wind, atmospheric composition and rainfall location, as well as conditions under which the plant is grown (Santos et al. 2004).

The essential oil from L. gracilis, with different saline treatments, showed bacteriostatic and bactericidal activity against Gram-positive and Gramnegative bacteria. The antimicrobial activity obtained in this study may be explained mainly by the phenylpropanoids carvacrol and thymol, compounds that are usually found in Lippia species and have shown action against bacteria and fungi. The essential oil from L. origanoides showed activity against bacteria such as methicillin-resistant Staphylococcus aureus, and the essential oil from L. menosides showed activity against Escherichia coli, Enterococcus faecalis, Salmonella enteritidis, Serratia marcescens, Candida albicans and Mycobacterium smegmatis. The antimicrobial activity was associated with the presence of the phenolic monoterpenes, carvacrol (41.77\%) and thymol (10.13\%) (Girón et al. 1991; Lacoste et al. 1986; Oliveira et al. 1990).

Essential oils are compounds that, for being hydrophobic, are easily diffused through the cell wall of microorganisms and cause damage to the membrane, especially with regard to fluidity and permeability (Millezi et al. 2012). Gram-negative bacteria, in general, have greater resistance to the action of essential oils, due to the greater complexity of their plasma membrane, which acts as a barrier to the diffusion of hydrophobic components of essential oils (Naik et al. 2010).

It is known that fish farming effluent has high levels of excrement and nutrients that can modify the characteristics of the fertigation solution in such a way to make its use unfeasible in other activities, such as in agriculture when using salinity-sensitive species (Mercante et al. 2004; Mainardes Pinto and Mercante 2003). The results of this study are relevant to the planning and management for the use of fish farming effluent, which is currently disposed of inadequately and without any utilization. In this context, the set of results obtained support the responses observed in the growth, anatomical and biochemical parameters, consolidating the indication of fish farming effluent used in this experiment for reuse in the irrigation of $L$. gracilis, an endemic species of the Caatinga and with pharmacological potential.

\section{Conclusions}

Acceptable biomass yield was maintained at all levels of salinity of the nutrient solution, composed of fish farming effluent; The high salinity of the effluent did not alter the leaf area and the relative water content associated with the production of sugars, pigments and activity of the enzymes of the antioxidant system, indicating that the fertigation of $L$. gracilis with saline effluent from fish farming did not affect the development of this species. The saline effluent from fish farming can be used in fertigation of L. gracilis without compromising the yield of plants, avoiding environmental contamination with disposal in soil and/or water bodies.

\section{Declarations}

\section{Ethics approval and consent to participate}

Not applicable

\section{Consent for publication}

Not applicable 
Availability of data and materials

The datasets used and/or analysed during the current study are available from the corresponding author on reasonable request.

\section{Competing interests}

The authors declare that they have no competing interests.

\section{Funding}

This work was supported by Universidade do Estado do Rio Grande do Norte and Coordenação de Aperfeiçoamento de Pessoal de Nível Superior (CAPES).

\section{Authors' contributions}

JMDSN and MBM participated in the data collection, designed the experiments, performed data analysis and wrote the manuscript; NSD provided the experimental area, performed physiological analyses and interpreted the results; LMS and CU participated in the anatomical analyses and interpreted and analyzed the data; JFS and MDF participated in the biochemical analyses; THSR, HSS, MAV and EHT participated in the analyses of essential oil composition and antimicrobial activity and interpreted the results; CCA guided every step of the study and participated in the drafting and reviewing of the project and of the article.

\section{Acknowledgment}

The authors gratefully acknowledge the Universidade do Estado do Rio Grande do Norte and Coordenação de Aperfeiçoamento de Pessoal de Nível Superior (CAPES), for support.

\section{References}

1. Albuquerque CC, Camara TR, Mariano RLR, Willadino L, Júnior C, Ulisses C (2006) Antimicrobial Action of the Essential Oil of Lippia gracilis Schauer. Braz Arch Biol. 49 (4): 527-535. doi: 10.1590/S1516-89132006000500001

2. Albuquerque CC, Camara TR, Sant'ana AEG, Ulisses C, Willadino L, Marcelino Júnior, C (2012) Effects of the essential oil of Lippia gracilis Schauer on caulinary shoots of heliconia cultivated in vitro. Rev Bras PI Med 14 (1): 26-33. doi: 10.1590/S1516-05722012000100005

3. Alexieva V, Sergiev I, Mapelli S, Karanov E (2001) The effect of drought and ultraviolet radiation on growth and stress markers in pea and wheat. Environment 24: 1337-1344. doi: 10.1046/j.1365-3040.2001.00778.x

4. Almodares A, Hadi M, Dosti B (2008) The effects of salt stress on growth parameters and carbohydrates contents in sweet sorghum. Res J Environ Sci 2: 298-304. doi: 10.3923/rjes.2008.298.304

5. Andersen A, Lucchini F., Moriconi J, Fernández EA. (2006) Variabilidad en la morfo-anatomía foliar de Lippia turbinata (verbenaceae) en la provincia de San Luis (Argentina). Int J Exp Bot 75: 137-143. Corpus ID: 82481718

6. Anjum S, Xie X, Wang L (2011) Morphological, physiological and biochemical responses of plants to drought stress. Afr J Agric Re 6: $2026-2032$. doi: $10.5897 / A J A R 10.027$

7. Appenroth KJ, Krech K, Keresztes A (2010) Effects of nickel on the chloroplasts of the duckweeds Spirodela polyrhiza and Lemna minor and their possible use in biomonitoring and phytoremediation. Chemosphere 78: 216-223. doi: 10.1016/j.chemosphere.2009.11.007

8. Ashraf M, Harris PJC (2013) Photosynthesis under stressful environments. Photosynthetica, 51: 163-190. doi: 10.1007/s11099-013-0021-6

9. Azevedo RA, Alas RM, Smith RJ, Lea PJ (1998) Response of antioxidante enzymes to transfer from elevated carbon dioxide to air and ozone fumigation, in the leaves and roots of wild-type and a catalase-deficient mutant of barley. Physiol Plant 104: 280-292

10. Bates LS, Waldren RP Teare ID (1973) Rapid determination of free proline for water-stress studies. Plant and Soil, 39, 205-207

11. Braga JMF, Pimental JMM, Ferreira CP, Randau KP, Xavier HS (2009) Morfoanatomia, histoquímica e perfil fitoquímico de Priva lappulacea (L.) Pers. (Verbenaceae). Revista Brasileira de Farmacognosia 19 (2): 516-523. doi: 10.1590/S0102-695X2009000400002

12. Bukatsch F (1972) Bemerkungen zur Doppelfärbung: Astrablau-Safranin. Mikrokosmos 61: 255.

13. Clinical and Laboratory Standards Institute (CLSI) (2017) Performance Standards for Antimicrobial Susceptibility Testing: Approved Standard $27^{\text {th }}$ ed. CLSI Document M100-S27. Wayne, PA: CLSI.

14. Costa CG, Callado CH, Coradin VTR, Carmello-guerreiro SM (2004) In: Apezzato-da-glória B, Carmello-guerreiro SM, Anatomia Vegetal. Editora UFV. 130-154. (438 páginas).

15. Cuoee I, Sulmon C, Gouesbet G, Amrani A (2006) Involvement of soluble sugars in reactive oxygen species balance and responses to oxidative stress in plants. J Exp Bot. 57 (3): 449-459. doi: 10.1093/jxb/erj027

16. Dantas BF, Ribeiro RC, Oliveira GM, Silva FFS, Araújo GGL (2019) Biosaline production of seedlings of native species from the Caatinga dry forest. Ciência Florestal 29 (4): 1551-1567. doi:10.5902/1980509831221

17. De Choudhury M, Counts S, Horvitz E (2013) Predicting Postpartum Changes in Behavior and Mood via Social Media. In Proc. CHI 2013, to appear

Page 12/18 
18. Domonkos I, Kis K, Gombos Z, Ughy B (2013) Carotenoids, versatile components of oxygenic photosynthesis. Prog Lipid Res 52 (4): $539-561$. doi: 10.1016/j.plipres.2013.07.001

19. Eller CB, Barros FV, Bittencourt PRL, Rowland L, Mencuccini M, Oliveira RS (2018) Xylem hydraulic safety and construction costs determine tropical tree growth. Plant Cell Environ 1-15. doi: 10.1111/pce.13106.

20. FAO - Food and agriculture organization., 2016. The state of world fisheries and aquaculture: opportunities and challenges. Rome: FAO, 243.

21. Fernandes LCB, Albuquerque CC, Sales Junior R, Oliveira FFM, Gurgel EP, Mesquita MV, Silva, MDS (2015) Fungitoxicidade dos extratos vegetais e do óleo essencial de Lippia gracilis Schauer sobre o fungo Monosporascus cannonballus Pollack e Uecker. Summa Phytopathol 41 (2): $153-155$. doi: $10.1590 / 0100-5405 / 1978$

22. Ferreira DF (2011) Sisvar: a computer statistical analysis system. Ciênc Agrotec (UFLA) 35: 1039-1042

23. Gil SS, Tujeta N (2010) Reactive oxygen species and antioxidant machinery in abiotic stress tolerance in crop plants. Plant Physiol Bioch 48: $909-$ 930. doi: 10.1016/j.plaphy.2010.08.016.

24. Giannopolitis CN, Ries SK (1977) Superoxide dismutases: I. Occurrence in higher plants. Plant Physiol 59: 309-314

25. Girón, LM, Freire V, Alonzo A, Cárceres A (1991). Ethnobotanical survey of the medicinal flora used by the Caribs of Guatemala. J Ethnopharmacol 34 (2-3): 173-187. doi: 10.1016/0378-8741(91)90035-C

26. Gomes SVF, Nogueira PCL, Moraes VRS (2011) Aspectos químicos e biológicos do gênero Lippia enfatizando Lippia gracilis Schauer. Eclet. Quím 36 (1): 64-77. doi: 10.1590/S0100-46702011000100005

27. Gondim FA, Gomes-Filho E, Marques EC, Prisco JT (2011). Efeitos do $\mathrm{H}_{2} \mathrm{O}_{2}$ no crescimento e acúmulo de solutos em plantas de milho sob estresse salino. Rev Ciênc Agron 42 (02): 373-381. doi: 10.1590/S1806-66902011000200016

28. Gupta B, Huang B (2014) Mechanism of salinity tolerance in plants: Physiological, biochemical, and molecular characterization. Int J Genomics ID 701596. doi: 10.1155/2014/701596

29. Gutierrez J, Barry-ryan C, Bourke P (2008) The antimicrobial efficacy of plant essential oil combinations and interactions with food ingredients. Int J Food Microbiol 124 (1): 91-97. doi: 10.1016/j.ijfoodmicro.2008.02.028

30. Havir E, McHale N (1987) Biochemical and developmental characterization of multiple forms of catalase in tobacco leaves. Plant Physiol 84: 450455. doi: 10.1104/pp.84.2.450

31. Henry-silva GG, Camargo AFM (2008) Impacto das atividades de aquicultura e sistemas de tratamento de efluentes com macrófitas aquáticas relato de caso. Bol Inst Pesca 34 (1): 163-173. doi: 10.1590/0100-5405/1978

32. Heath RL, Packer L (1968) Photoperoxidation in isolated Chloroplasts. I. Kinetics and stoichiometry of fatty acid peroxidation. Arch Biochem Biophys 125:189-198

33. Hu M, Shi Z, Zhang Z, Zhang Y, Li H (2012) Effects of exogenous glucose on seed germination and antioxidant capacity in wheat seedlings under salt stress. Plant Growth Regul 68 (2): 177-188. doi: 10.1007/s10725-012-9705-3

34. Johansen DA (1940) Plant microtechnique. New York: Mcgraw-Hill Book. 523 p.

35. Kibria MG, Hossain M, Murata Y, Hoque MD (2017) A. Antioxidant Defense Mechanisms of Salinity Tolerance in Rice Genotypes. Rice Sci 24(3): 155-162. doi: 10.1016/j.rsci.2017.05.001

36. Lacoste E, Chaumont JP, Mandin D, Plumel M, Matos FJ (1996) Le propriétés antiseptiques de I'hule essentielle de Lippia sidoidides Cham. Aplication à la micoflore cutanée. Ann Pharm Fr 54(5): 228-230.

37. Lei B (2014) Scanning ion-selective electrode technique and X-ray microanalysis provide direct evidence of contrasting $\mathrm{Na}^{+}$transport ability from root to shot in salt-sensitive cucumber and salt-tolerant pumpkin under $\mathrm{NaCl}$ stress. Physiol Plant 152: 738-748. doi: 10.1111/ppl.12223.

38. Li XP, Bjorkman O, Shih C, Grossman AR, Rosenquist M, Jansson S, Niyogi KK (2000) A pigment-binding protein essential for regulation of photosynthetic light harvesting. Nature 403: 391-395. doi: 10.1038/35000131

39. Mainardes-pinto CSR, Mercante CTJ (2003) Avaliação de variáveis limnológicas e suas relações com uma floração de Euglenaceae pigmentada em viveiro povoado com tilápia do Nilo (Oreochromis niloticus Linnaeus), São Paulo, Brasil. Acta Scientiarum. Biol Sci 25 (2): $323-328$. doi: $10.4025 /$ actascibiolsci.v25i2.2018

40. Marijuan MP, Bosch SM (2013) Ecophysiology of invasive plants: osmotic adjustment and antioxidants. Trends Plant Sci 18: 660-666. doi: 10.1016/j.tplants.2013.08.006.

41. Mercante CTJ, Cabianca MA, Silva D, Costa SV, Esteves KE (2004) Water quality in fee-fishing ponds located in the metropolitan region of São Paulo city, Brazil: an analysis of the eutrophication process. Acta Limnol Bras, 16 (1): 95-102.

42. Millezi AF, Caixeta DS, Rossoni DF, Cardoso MG, Piccoli RH (2012) In vitro antimicrobial properties of plant essential oils thymus vulgaris, cymbopogon citratus and laurus nobilis agains five important foodborne pathogens. Ciência e Tecnologia de Alimentos 32 (1): $167-$ 172. doi: 10.1590/S010120612012005000021.

43. Miranda RS, Gomes-Filho E, Prisco JT, Alvarez-Pizarro JC (2016) Ammonium improves tolerante to salinity stress in Sorghum bicolor plants. Plant Growth Regul 78: 121-131. doi: 10.1007/s10725-015-0079-1

44. Miller GL (1959) Use of dinitrosalicylle acid for determination of reducing sugar. Anal Chem 11: 426-428

45. Morais L (2009) Influência dos fatores abióticos na composição química dos óleos essenciais. Hortic Bras 27: 4050-4063. ID: S4050-S4063.

Page 13/18 
46. Munns R, Tester M (2008). Mechanisms of salinity tolerance. Annu Rev Plant Biol 59: 651-81

47. Naik MI, Fomda BA, Jaykumar E, Bhat JA (2010) Antibacterial activity of lemongrass (Cymbopogon citratus) oil against some selected pathogenic bacterias. Asian Pac J Trop Medicine 1 (1): 535-538. doi: 10.1016/S1995-7645(10)60129-0

48. Nakano Y, Asada K (1981) Hydrogen-peroxide is scavenged by ascorbate-specific peroxidase in spinach-chloroplasts. Plant Cell Physiol 22: 867880

49. Neffati M, Marzouk B (2008) Changes in essential oil and fatty acid composition in coriander (Coriandrum sativum L.) leaves under saline conditions. Ind Crop Prod 28: 137-142. doi: 10.1016/j.indcrop.2008.02.005

50. Negrão S, Schmöckel SM, Tester M (2017) Evaluating physiological responses of plants to salinity stress. Ann. Bot. 119: 1-11. doi: 10.1093/aob/mcw191

51. Oliveira AB, Raslan DS, Miraglia MC, Mesquita AA L, Zani CL, Ferreira DT, Maia JGS (1990) Chemical structures and biological activities of naphthoquinones from Brazilian Biognoniaceae. Quím Nova 13 (4): 302-307

52. Oliveira EG, Santos FJS (2011) Conservação e uso racional de água: Integração aquicultura-agricultura. In: MEDEIROS, S. S.; GHEYI, H. R.; GALVÃO, C. O.; PAZ, V. P. S. (Eds). Recursos hídricos em regiões áridas e semiáridas. Campina Grande: Instituto Nacional do Semiárido, p.113-161.

53. Oliveira FFM, Morais MB, Silva MES, Saraiva YKF, Arruda MVM, Silva JNC, Albuquerque CC (2019) Ecophysiological response of Lippia gracilis (Verbanaceae) to duration of salt stress. Ecotox Environ Safe 178:202-210. doi: 10.1016/j.ecoenv.2019.04.016

54. Oussalah M, Caillet S, Saucier L, Lacroix M (2007) Inhibitory effects of selected plant essential oils on the growth of four pathogenic bacteria: E. coli 0157:H7, Salmonella Typhimurium, Staphylococcus aureus and Listeria monocytogenes. Food Control 18 (5): $414-420$. doi: 10.1016/j.foodcont.2005.11.009

55. Pascual ME, Slowing K, Carretero E, Sánchez-Mata D, Villar A (2001) Lippia: Traditional uses, chemistry and pharmacology: A review. J Ethnopharmacol 76 (3): 201-214. doi: 10.1016/S0378-8741(01)00234-3

56. Ragagnin RCG; Albuquerque CC, Oliveira FFM, Santos RG, Gurgel EP, Diniz JC, Rocha SAS, Viana FA (2014) Effect of salt stress on the growth of Lippia gracilis Schauer and on the quality of its essential oil. Acta Bot Bras 28: 346-351. doi: 10.1590/0102-33062014abb3369.

57. Richards LA (1947) Pressure-membrane apparatus, construction and use. Agro Eng Madison 28: 241-247.

58. Sánchez-Aguayo I, Rodriguez-Galán JM, García R, Torreblanca J, Pardo JM (2004) Salt stress enhances xylem development and expression of Sadenosyl-L-methionine synthase in lignifying tissues of tomato plants. Planta 220: 278-285. doi: 10.1007/s00425-004-1350-2

59. Santelia D, Lawson T (2016) Rethinking Guard Cell Metabolism. Plant physiol 172: 371-724. doi:10.1104/pp.16.00767.

60. Santos MRA, Innecco R, Soares AA (2004) Caracterização anatômica das estruturas secretoras e produção de óleo essencial de Lippia alba (Mill.) N.E. Br. em função do horário de colheita nas estações seca e chuvosa. Rev Ciênc Agron 35(2): 377-383.

61. Santos RF, Carlesso R (1998) Déficit hídrico e os processos morfológico e fisiológico das plantas. Agriambi 2 (3): 287-294. doi: 10.1590/18071929/agriambi.v2n3p287-294.

62. Schneider CA, Rasband WS, Eliceiri KW. 2012. NIH Image to ImageJ: 25 years of image analysis. Nat Methods 9: $671-675$.

63. Sewelam N, Kazan N, Schenk PM (2016) Global Plant Stress Signaling: Reactive Oxygen Species at the Cross-Road Front Plant Sci 7 (187): 1-21. doi: $10.3389 /$ fpls.2016.00187

64. Silva MBR, Fernandes PD, Neto JD, Nery AR, Rodrigues LN, Viégas RA (2011) Crescimento e produção do pinhão-manso irrigado com água residuária sob condições de estresse hídrico. Agriambi 15: 621-629. doi: 10.1590/S1415-43662011 000600013

65. Silva FAS (2015) ASSISTAT version 7.6 beta. Campina Grande-PB: Assistance Statistics, Department of Agricultural Engineering CTRN - Federal University of Campina Grande, Campina Grande Campus.

66. Silveira PS, Custódio JPC, Silva FCM, Nascente ACS, Monteiro CL, Matos FS (2016) A ação dos brassinosteróides no crescimento de mudas de pinhão manso sob déficit hídrico. Agri-Enviroment Sci 2 (1): 52-61.

67. Souza TJT, Manfron MP, Zanetti GD, Hoelzel SCSM, Pagliarin VP (2005) Análise Morfo-Histológica e Fitoquímica de Verbena litoralis Kunth. Acta Farm Bonaerense 24 (2): 209-14

68. Van Genuchten MT (1980) A closed-form equation for predicting the hydraulic conductivity of unsaturated soils. Soil Sci Soc Am J 44 (5): $892-898$. doi: 10.2136/sssaj1980.03615995004400050002x

69. Vale JPC, Ribeiro LHF, Vasconcelos MA, Sá-Firmino NC, Pereira AL, Nascimento MFD, Rodrigues THS, Silva PTD, Sousa KC, Silva RBD, NascimentoNeto LGD, Saker-Sampaio S, Bandeira PN, Santos HS, Souza EB, Teixeira EH (2019). Chemical composition, antioxidant, antimicrobial and antibiofilm activities of Vitex gardneriana Schauer leaves's essential oil. Microb Pathog 135. doi: 10.1016/j.micpath.2019.103608

\section{Figures}


A

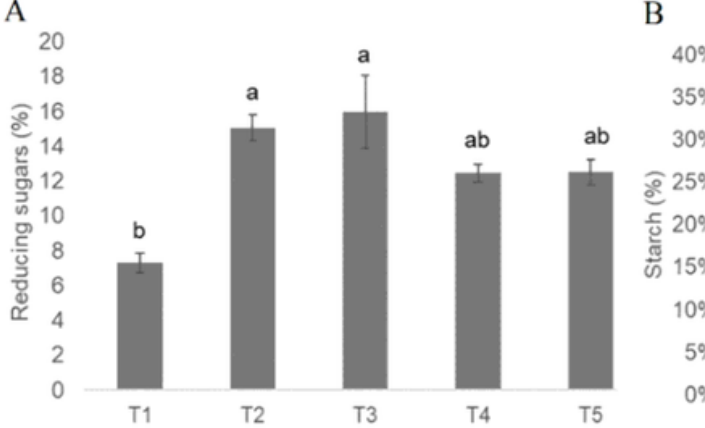

$\mathrm{C}$

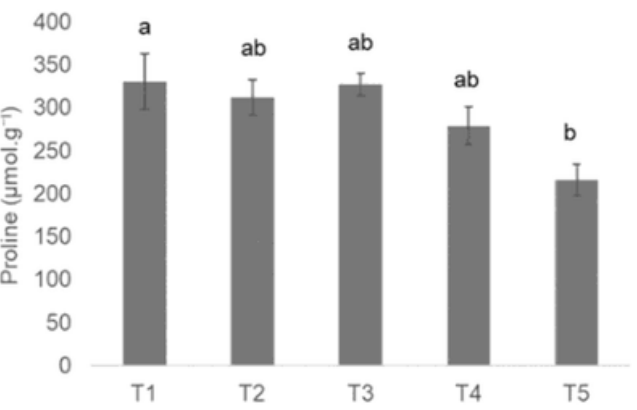

Figure 1

Effect of fish farming effluent on reducing sugars (A), starch (B) and proline (C) in L. gracilis plants $\left(\mathrm{T} 1=452 \mu \mathrm{S} ; 2.68 \mathrm{dS} \mathrm{m}^{-1} ; \mathrm{T} 2=4.60 \mathrm{dS} \mathrm{m}^{-1} ; \mathrm{T}^{-1}=5.55\right.$ dS m-1; T4=5.55 dS m-1; and T5=7.02 dS m-1). Means followed by the same letters do not differ statistically by Tukey test at $5 \%$ probability level.
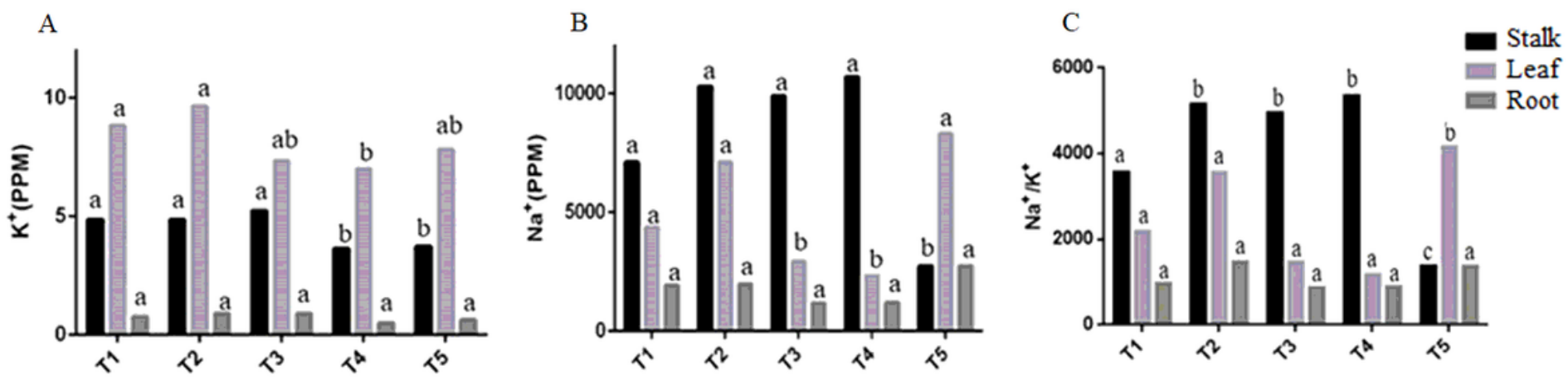

\section{Figure 2}

$\mathrm{Na}(\mathrm{A}), \mathrm{K}(\mathrm{B})$ and $\mathrm{Na} / \mathrm{K}(\mathrm{C})$ levels in L. gracilis irrigated with saline effluent from fish farming. $\left(\mathrm{T} 1=452 \mu \mathrm{S} ; 2.68 \mathrm{dS} \mathrm{m}^{-1} ; \mathrm{T}^{2}=4.60 \mathrm{dS} \mathrm{m}^{-1} ; \mathrm{T}^{2}=5.55 \mathrm{dS} \mathrm{m}^{-1}\right.$; $\mathrm{T} 4=5.55 \mathrm{dS} \mathrm{m}{ }^{-1}$; and T5=7.02 dS $\mathrm{m}^{-1}$ ). Means followed by the same letters do not differ statistically by Tukey test at $5 \%$ probability level.

A

60

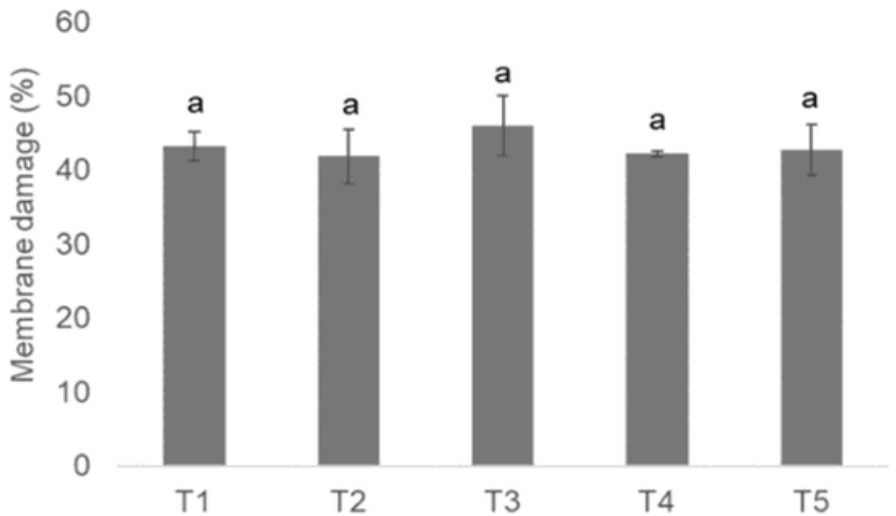

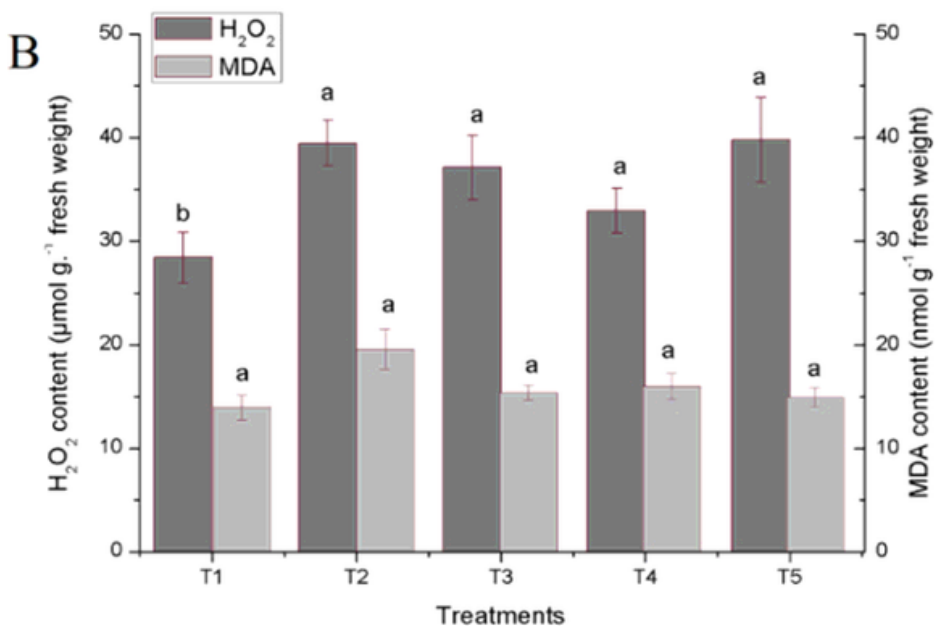

Figure 3

Effect of fish farming effluent on membrane damage (\%) (A), hydrogen peroxide content (H2O2) (B) and lipid peroxidation expressed by malondialdehyde (MDA) content in L. gracilis plants (T1=452 $\mu \mathrm{S} ; 2.68 \mathrm{dS} \mathrm{m}^{-1} ; \mathrm{T}_{2}=4.60 \mathrm{dS} \mathrm{m}^{-1}$; T3= $5.55 \mathrm{dS} \mathrm{m}^{-1}$; T4=5.55 dS m-1; and T5=7.02 dS m-1). Means followed by the same letters do not differ statistically by Tukey test at $5 \%$ probability level. 


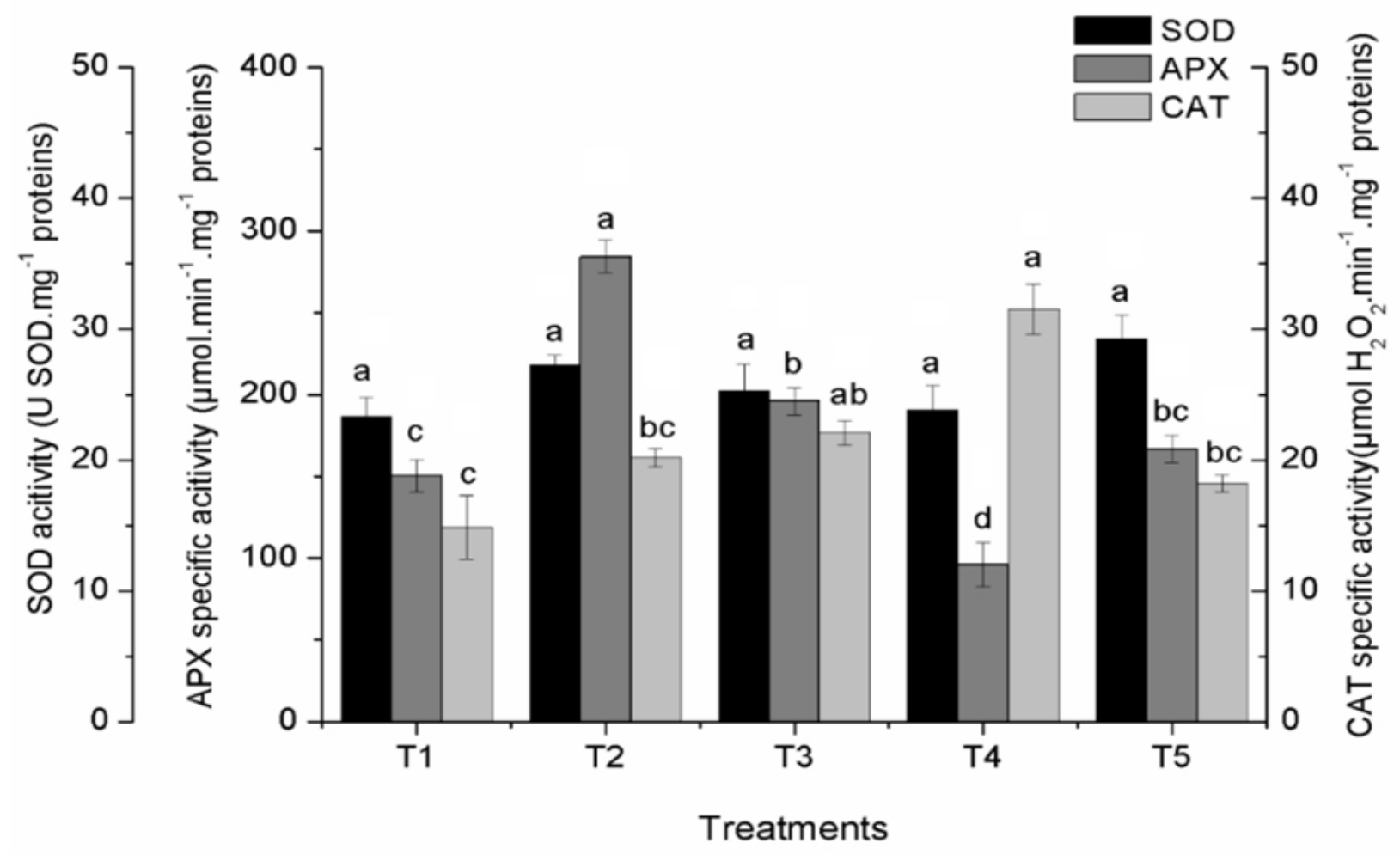

Figure 4

Effect of fish farming effluent on the activity of the oxidative metabolism enzymes superoxide dismutase (SOD), ascorbate peroxidase (APX) and

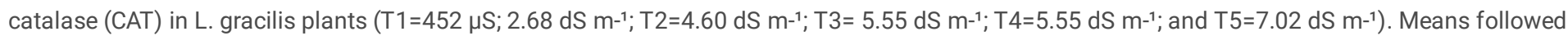
by the same letters do not differ statistically by Tukey test at $5 \%$ probability level. 


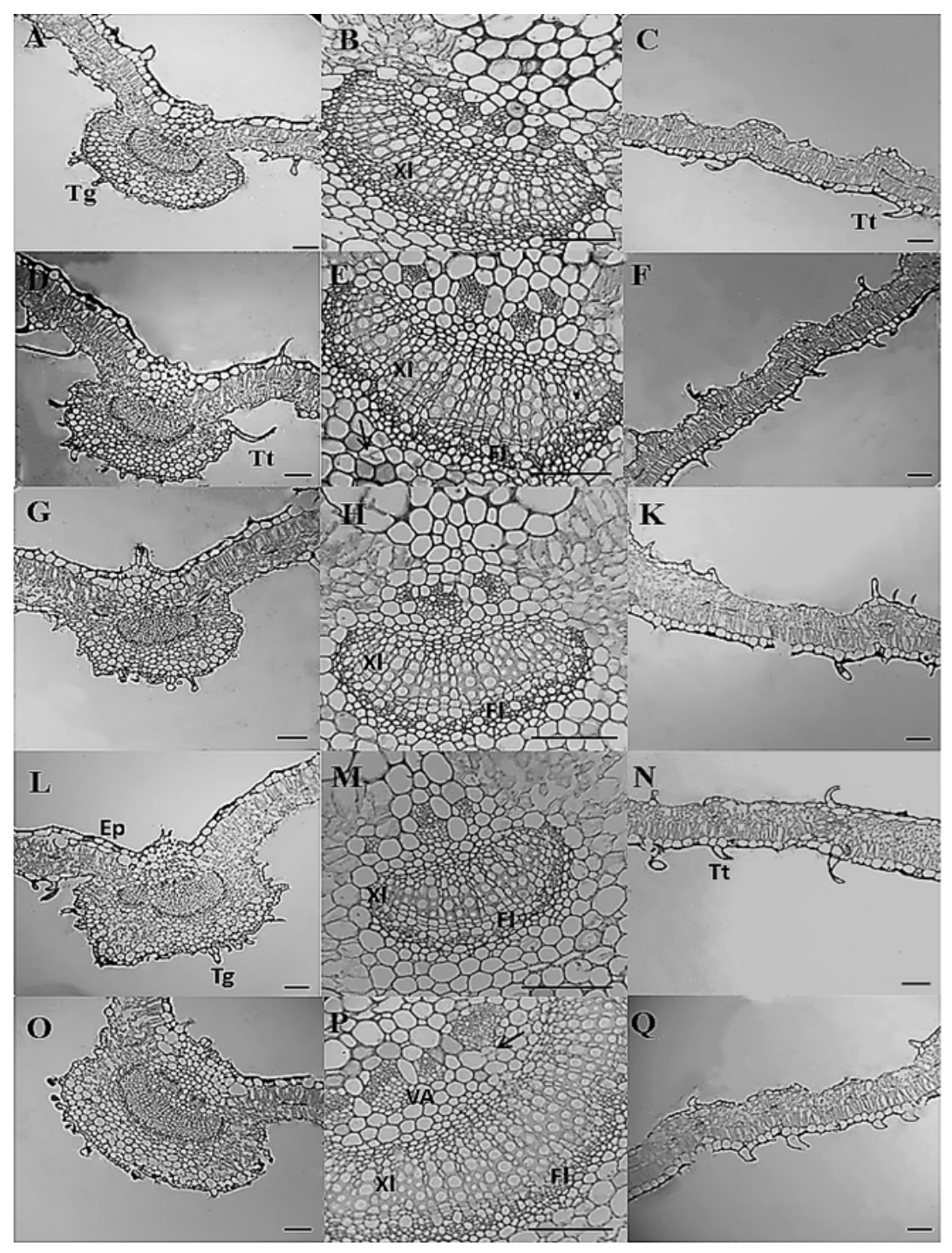

\section{Figure 5}

Photomicrographs of cross-sections of leaves of $L$. gracilis cultivated under irrigation with fish farming effluent. T1=452 $\mu S(A-C)$; T2=2.68 dS m-1 (D-F); $\mathrm{T} 3=4.60 \mathrm{dS} \mathrm{m}^{-1}$ (G-K); T4=5.55 dS m-1 ; (L-N); T5=7.02 dS m-1 (O-Q). Tng= Non-glandular trichome; Tg= Glandular trichome; Xyl= xylem; Phl= phloem; $\mathrm{Ep}=$ epidermis; $\mathrm{AV}=$ Auxiliary vessels; Arrows $=$ Raphides. $($ Scale $=50 \mu \mathrm{m})$. 


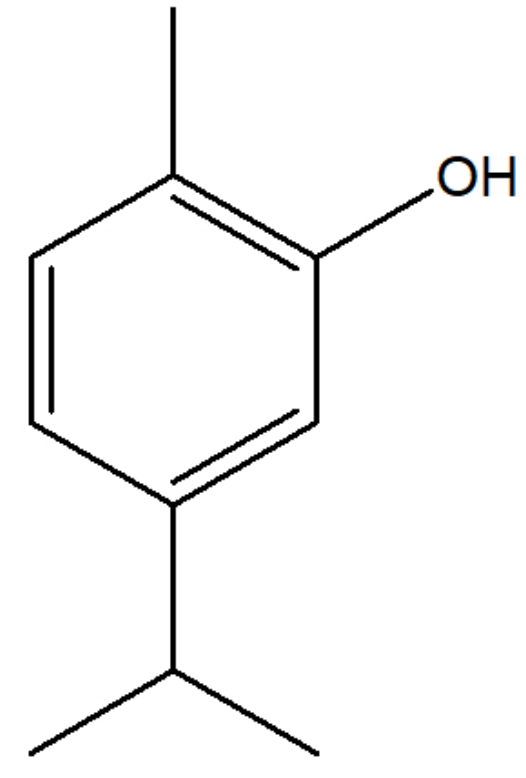

1

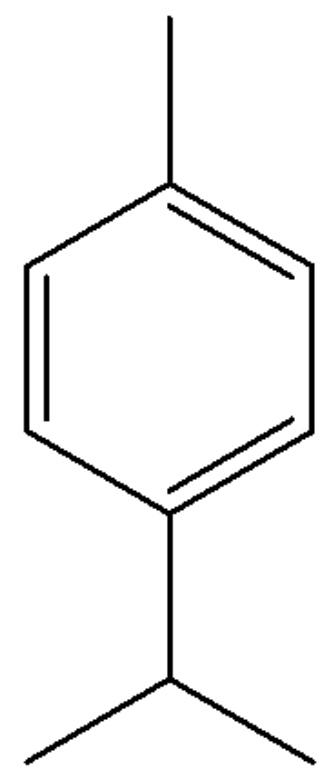

2

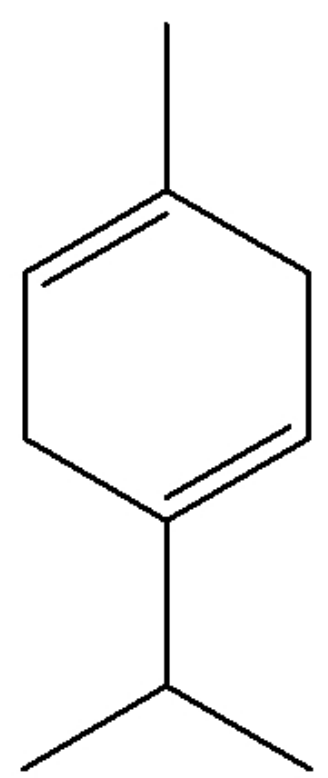

3

Figure 6

Major components in the essential oil from L. gracilis leaves. 